\title{
Primal fear: A Darwinian perspective on Dan Simmons' Song of Kali
}

\section{ABSTRACT}

1.

2.
The emerging evolutionary approach to literature explores the way that culture and biology interact. As a branch of evolutionary literary criticism, Darwinian horror study sees horror fiction as crucially dependent on evolved properties of the human constitution. This article argues that a Darwinian perspective on Dan Simmons' 1985 novel Song of Kali best explains the atheist author's preoccupation with themes of the supernatural, and accounts for the novel's emotional impact as a result of humanity's evolutionary history.

Dan Simmons' debut novel Song of Kali from 1985 is a depressing, frightening, disturbing and engaging novel that is centrally concerned with the nature of evil, and that relies heavily on tropes of the supernatural. Why would Simmons, a self-professed atheist and rationalist, write a story so reliant upon the allure and the suggestive power of the supernatural? How and why does the story work its emotional designs on the reader? And, finally, what does evolution have to do with it?

To answer these questions, we need to look beyond what is printed on the pages of the book. We need to look further than Simmons' biography, and further than the histories of modern horror fiction. We need, in fact, to

\section{KEYWORDS}

Song of Kali

Dan Simmons

supernatural horror Darwinian criticism

evolution

emotions 
look into the deep past of our species: into prehistory, into a time when our ancestors were in daily (or nightly) mortal danger of being eaten by predators. It is a tale that takes its beginnings with the advent of organic life on Earth. In this article, I delineate the Homo timidus theory of horror fiction, the theory that horror fiction is crucially dependent on evolved properties of the human central nervous system. I affirm that fear and anxiety are defining affective features of horror fiction, trace the evolution of these emotions, and assert that attention to evolved psychology can explain salient structures of horror fiction. Moreover, an evolutionary perspective, I argue, can constitute the basis for a consilient reading of a specific piece of literature, in this case, Song of Kali.

\section{HUMAN EVOLUTION AND LITERARY STUDY}

You want to scare somebody, so you hide behind a door, wait for your victim to approach, and then jump out and yell 'BOO!'

It works. But why? It works because humans come factory equipped with an intricate neurophysiological apparatus that helps them to cope with danger. The ability to keenly monitor and appropriately react to predators is an adaptation in the biological sense, a complex functional mechanism that has improved our ancestors' odds of survival and propagation. So when you jump out and yell at your friend, he or she ideally reacts as though you were a predator on the savannah: the parasympathetic nervous system takes over and prepares the organism for action. The powerful startle reflex causes a swift contraction of leg and arm muscles, preparing the organism for violent action and hunching the shoulders to protect the neck from attack. Adrenaline is pumped into the bloodstream, heart rate and blood pressure go up, blood is diverted away from the gut and to the large muscles (all to prepare your friend for fighting or fleeing you). Pupils are dilated and tunnel vision may set in, and awareness is heightened and sharply focused (to help your friend stay with the programme and focus on the threat, not your nice new wallpaper). The production of saliva is inhibited (digestion is irrelevant for the time being). Hair stands on end (an atavism from a hairier past when piloerection would make your friend seem bigger and more fearsome), and glucose is pumped into the blood (a quick energy fix in anticipation of urgent evasion or violent conflict). Time is of the essence when faced with a threat, so the adaptive fear response is quick and dirty. Even the slightest cue of danger may set it off, since a false positive is better than a false negative: shrug at what turns out to be a leopard in the bush, and your fitness quotient drops to nil rather swiftly. Jump at shadows, and the worst that can happen is that you waste your energy (Marks and Nesse 1994).

Our species, Homo sapiens sapiens, has been a very long time underway, and like all other organisms, ours is the product of a long and relentless evolutionary process of adaptation. Adaptations are functional mechanisms that have been selected for because they improve the organism's odds of survival and reproduction. Our deep past is, even today, stamped into our bodies and minds. This was Darwin's insight, that organisms evolve in an adaptive relationship with their environments, including members of their own species and other organisms (Darwin 1859). Individuals are born with different characteristics, some of which have consequences for the individual's chances of survival and reproduction. Some individuals survive and reproduce in greater frequencies than their peers; thus, well-adapted genes become widespread in the population. Over long periods of time and many generations, quite

1. 2. 
complex adaptations can arise as a result of natural selection: chromatic vision, for example, or the neurophysiological fear response.

Although Darwin was careful not to dwell on the particularly contentious topic of human evolutionary history in On the Origin of Species, he turned his attention fully to that subject in subsequent works, especially The Descent of Man (1871) and The Expression of the Emotions in Man and Animals (1872). Darwin was the first scholar to systematically investigate human psychology as a product of selection, and other scholars have since carried on this research programme. The zoologist E. O. Wilson brought sociobiology to contested prominence in the 1970s (see e.g. Wilson 1975), and evolutionary psychology flourished from around 1990. Whereas sociobiology applies to all social animals, evolutionary psychology focuses on humans and has strong cognitive leanings (see e.g. Pinker 2002). Evolutionary psychology views the human mind as an adaptive organ, one shaped by eons of incessant natural and sexual selection. In the vulgar view, we are cavemen and cavewomen confusedly milling about on the information highways of the twenty-first century; in the more sophisticated view, the human mind consists of a large number of adaptations that have been fine tuned by evolutionary processes to create organisms fit for survival and reproduction in ever-changing environments.

Some literary scholars were quick to realize the potentially revolutionary potential of evolutionary thought if applied to their field. All literary theory is predicated on a theory of psychology, whether implicitly or explicitly, and if psychology is undergoing a revolution (cf. Barkow 2006), then so should literary study. The godfather of evolutionary literary study, Joseph Carroll, has since the mid-1990s been working on a literary theory and criticism that is consistent with evolutionary social science. Now, fifteen years later, publications in evolutionary literary theory are rising exponentially in number (cf. Carroll 2010). Most evolutionary literary scholars have focused their attention on canonical literature such as Shakespeare, Homer and Austen (e.g. Carroll 2004; Boyd 2009; Gottschall 2008), whereas genre fiction has with some notable exceptions remained virgin land to Darwinian critics. Brett Cooke (2002), another founder of the field, has worked with science fiction and particularly dystopia, and David Swanger has published an impressive study of science fiction and horror sustained by cognitive and evolutionary psychology (2008; see also overview in Clasen 2010a). My main point here is that horror theory has much to gain from adopting a Darwinian perspective.

\section{THE BIOLOGICAL SUBSTRATE OF HORROR FICTION}

As H. P. Lovecraft famously claimed in his essay Supernatural Horror in Literature, "The oldest and strongest emotion of mankind is fear, and the oldest and strongest kind of fear is fear of the unknown'. As a logical consequence, he implied, horror fiction is the oldest kind of storytelling: 'As may naturally be expected of a form so closely connected with primal emotion, the horror tale is as old as human thought and speech themselves' $(1973: 12,17)$. He was probably onto something, but since the archaeological record holds no traces of prehistoric oral literature, we may never know for certain.

We do know, however, that fear is a so-called 'basic emotion' (Ekman 1992). Fear is at the core of our being, obviously adaptive, and it extends millions of years back along our evolutionary history. Without fear, our ancestors would not have survived long in dangerous environments. According to the psychologist Arne Öhman, 'responses of fear and anxiety originate in 
an alarm system shaped by evolution to protect creatures from impending danger. This system is biased to discover threat, and it results in a sympathetically dominated response as a support of potential flight or fight' (2000: 587). In other words, humans are hard-wired to jump at shadows, and find it difficult to consciously extinguish a fear response, even when the shadows upon anxious inspection turn out to be just that, and not a ghost or a crouching leopard.

Life in prehistoric times was dangerous. Early humans were under constant threat from predators (human and non-human ones alike), natural disasters, accidents and invisible but lethal pathogens. Prehistoric humans were prey as well as hunters. We know from the fossil record that attacks on our ancestors from fierce mammalian predators happened regularly (Hart and Sussman 2009), and it would be rather odd if millions of years spent as prey had not left a stamp on our bodily and mental frame, if the sight of a fearsome, bloodthirsty predator did not evoke an uneasy primeval shudder today still.

As the natural historian David Quammen puts it:

Great and terrible flesh-eating beasts have always shared landscape with humans. They were part of the ecological matrix within which Homo sapiens evolved. They were part of the psychological context in which our sense of identity as a species arose. They were part of the spiritual systems that we invented for coping. The teeth of big predators, their claws, their ferocity and their hunger, were grim realities that could be eluded but not forgotten [...] Among the earliest forms of human selfawareness was the awareness of being meat.

Quammen's assertion has been bolstered by experimental evidence that suggests that our interest is preferentially engaged by possible threats in the environment. Ancient, atavistic threats live on as ghosts in the human central nervous system. Even ambiguous perceptual cues that seem to suggest the presence of a predator foster attention and arousal: a facing pair of eye-spots, a pattern that resembles the rosettes on a leopard's coat, the teeth-like leaves of Spanish Dagger (Coss and Goldthwaite 1995; Coss 2003; see also Öhman and Mineka 2001). The psychologist Richard G. Coss, who has studied antipredator behaviour in a range of species, concludes that humans 'might retain perceptual and cognitive relics under relaxed selection exceeding the millionyear time frame' (Coss and Goldthwaite 1995: 196). He finds that 'fascination with leopard rosettes and python scales can be detected in infants as young as 7 months of age'. Possibly, he says, this is a 'precursor to pattern-recognition processes that emerge later in development as animal fears' (Coss 2003: 112). Many species, including primates, are born with predator schema coded into their genomes, yet require environmental input to trigger these schema. Thus, for example, rhesus macaques learn to fear toy crocodiles and snakes after observing other members of their species reacting fearfully to these objects; when the macaques see doctored footage that appears to show monkeys behaving fearfully to flowers or rabbits, the macaques do not develop flower or rabbit fear as a result (Coss 2003: 105).

Of course, in industrialized society, the odds of being attacked by the kind of 'fast-moving mammalian predators' (Barrett 2005: 201) that regularly pounced on hapless humans and ancestral hominids are slim. But even modern humans in industrialized civilization are born with the neurobiological

1. 2. 3. 4. 5. 6. 7. 8. 9. 10. 11. 12. 13. 14. 15. 16. 
44. rigging that helped their remote ancestors survive. We retain our keen interest in animals as potential resources as well as threats. Brian Boyd has demonstrated the ubiquity of animals in literature from diverse periods and places (2007), and a clever experimental set-up revealed that when test persons are shown pictures of a 'complex natural scene' for 250 milliseconds and then equally briefly shown an almost-identical version where a detail is omitted, they were faster and more reliable in detecting the change when it involved an animal or a human than when it involved objects that played no part in ancestral environments, such as coffee mugs or Volkswagen vans. The authors of the study posit an 'animate monitoring bias' of evolutionary origin: our ancestors did not need to monitor fast-moving lumps of metal, even though the failure to quickly spot an oncoming automobile has potentially fatal consequences in modern environments. This is something we need to learn. Yet because of millions of years of natural selection, we are hard wired to preferentially attend to human as well as non-human agents in the environment (New et al. 2007). It is a finding that accounts for the fact that most parents spend massive amounts of time trying to teach their offspring to mind the traffic when crossing the street, whereas making them keep a safe distance from large animals requires much less effort.

In other words, we have experimental evidence that human interest is preferentially biased as a likely result of our species' evolution. The psychologist Hank Davis and his colleagues set up a study to determine whether people's apparently insatiable appetite for sensationalist news is purely a cultural construction. They examined a range of news stories published between the years 1700 and 2001 and in various cultures, and they found that the topics of sensational news stories are distributed non-randomly, often falling into categories that would have been of vital importance in our evolutionary past. For example, many stories were categorized as dealing with 'altruism, reputation, cheater detection, violence, reproductive strategies and the treatment of offspring'. As the authors furthermore note, 'stories about animal attacks, deadly parasites and tainted food sources remain salient topics', even though such concerns have become 'marginal in industrialized nations' (Davis and McLeod 2003: 214).

Apart from a range of mammalian predators, snakes have for millions of years preyed on our ancestors. In fact, snakes and mammals have co-evolved for as long as 60-odd million years, according to research performed by the anthropologist Lynne Isbell (2006). Poisonous spiders, similarly a frequent target of human phobia today, have also historically constituted a lethal risk to our less robust hominid ancestors (Rakison and Derringer 2008). A fascination with dangerous animals, likely a relic of our evolutionary past, thus gives rise to a range of modern-day behaviours and may 'cause people to enjoy predator-prey related entertainment such as films and video games [...] which might be dubbed the "Jurassic Park hypothesis"', in H. Clark Barrett's words (2005: 218).

Thus, what appears to be an evolved propensity to pay special attention to, for example, dangerous animals survive anachronistically and is capitalized upon by horror stories that feature such animals. Many horror monsters are essentially ferocious predators, however tweaked; most 'classical' monsters perform some breach of ontology or other, for example by violating the traditional divide between humans and animals (werewolves), the divide between living and dead (vampires and zombies), or by tinkering with what we normally expect of human biology (ghosts). As Noël Carroll says, monsters 
of horror fiction are 'categorically interstitial' (1990: 32). There is no shortage of fearsome creatures with sharp teeth and claws in horror fiction, and we also find plenty of snakes and spiders. For example, in Dan Simmons' Summer of Night (1991), the horrible burrowing monsters that serve Evil are like huge snakes: they have six-inch teeth (1991: 576), scales (1991: 302), are more than 35-feet long (1991: 306), and are described as 'giant serpents' and 'serpent-slug things' (1991: 303). The thing that hides in Dale and Lawrence's cupboard (and under their bed) is only glimpsed, but we learn that it has a 'hand with claws' (1991: 277). And the mother-monster, encountered in Old Central at the end of the story, is a spider-like horror (1991: 596) with no clearly discernible features, apart from those essential tools in the predator's kit: eyes and a mouth (1991: 621).

Another central fear motif in Summer of Night is darkness. In a central, haunting scene, Dale is trapped in a pitch-dark basement with a decomposing corpse (Simmons 1991: 344-45). Fear of the dark is a ubiquitous fear that seems to arise with the onset of other childhood anxieties around the age of 2 , and it is likely a consequence of our species' poor night vision, as well as the reasonable conjecture that, as Coss curtly states, 'nighttime in the savanna woodlands [was] dangerous' (2003: 82). Darkness obscures the presence of predators, and our imaginations project all manner of monstrosities onto blank canvases. So many monsters cavort only or preferably at night; so many paperback horror novels are bound in black and contain words like 'dark' and 'night' in their titles. As Stephen King put it in an interview, 'The dark can have teeth, man!' (Norden [1983] 1988: 28).

In Lovecraft's suggestive phrasing, 'sometimes a curious streak of fancy invades an obscure corner of the very hardest head; so that no amount of rationalisation, reform, or Freudian analysis can quite annul the thrill of the chimney-corner whisper or the lonely wood' (1973: 13). Modern evolutionary psychology and the cognitive science of religion have vindicated Lovecraft's claim that this psychological phenomenon, the tendency to jump at shadows and project supernatural agency onto the inexplicable, is 'part of our innermost biological heritance' (1973: 13), a result of natural selection and coded into our species' DNA (e.g., Boyer 2002; Barrett 2004):

Man's first instincts and emotions formed his response to the environment in which he found himself [...] The unknown, being likewise the unpredictable, became for our primitive forefathers a terrible and omnipotent source of boons and calamities visited upon mankind for cryptic and wholly extra-terrestrial reasons [...] there is an actual physiological fixation of the old instincts in our nervous tissue, which would make them obscurely operative even were the conscious mind to be purged of all sources of wonder.

(Lovecraft 1973: 13-14)

Horror fiction, it seems, dips into a conserved reservoir of primeval fear (cf. Clasen 2010a, 2010b). We have lived with monsters for millions of years. Ironically, now that industrialized civilization has all but wiped out the threat from big cats and poisonous snakes, we have reinstated the old enemies on the silver screen and the printed page. This is the observation that the Homo timidus theory tries to account for.

Fred Botting, a prominent critic of the Gothic, writes that the figures and monsters of horror stories provide 'embodiments and evocations of cultural

1. 2. 3. 4. 5. 6. 7. 8. 9. 10. 11. 
anxieties' (1996: 2). This is so, but there is more to the power of the monstrous, a deeper layer of resonance that should be located not in cultural configurations, but in the depths of the human mind and in the evolutionary forces that have shaped our species. The Homo timidus theory of horror fiction is still in its infancy, but once we manage to integrate the evolutionary explanation with a historicist perspective, we will have a very powerful explanatory framework with a deep causal reach. We can then understand why horror stories generally travel well in time and space, even as horror stories are partly products of their cultural ecologies; we can understand why even atheist writers from Lovecraft to T. E. D. Klein and Joe R. Lansdale are attracted to motifs of supernatural horror; we can account for the strange fascination with horrible monsters and protagonists in terrible straits that figure prominently in horror stories; why the gallery of horror fiction is populated by a few archetypes, and simultaneously why the vampire is popular in one era and the ghost in another; we can, in short, account for the raw, atavistic power of the well-told tale of horror, and explain the complex interplay of cultural expression and evolved biology.

I turn now to Song of Kali as a test case for a Darwinian reading. The novel seems clearly designed to elicit a range of negative emotional responses from its reader, and I look at a few selected scenes to account for the way that the author attempts to manipulate emotional reader response by evoking scenarios that strike dark chords in human nature.

\section{A DARWINIAN READING OF SONG OF KALI}

The short introductory passage that prefaces the actual narrative of Song of Kali is fraught with portentousness and dark significance, and it performs several tasks. It sets the locale (events are going to unfold in Calcutta), alerts the reader to genre (said events are likely to be nasty and horrifying), and attempts to establish an informational void (what events could be nasty enough to make the narrator wish for nuclear destruction to be heaped on Calcutta?). This latter is a task that all literature attempts to perform: convince the reader that this story is worth his or her attention and time, that is, convince the reader that the storyteller has information that will be of high interest to the reader. Information matters to humans, as it does to all other organisms (even the sunflower needs to know in which direction to grow, the dung beetle what to eat and what to avoid); information is crucial to survival, and so we have an adaptive appetite for information that we perceive to be relevant to us. This appetite, as we have seen in the case of Davis' research on sensationalistic news stories, is non-randomly distributed, biased towards themes of adaptive significance: themes of mating, survival, parent-offspring relations, resource allocation, and so on. A story of the kind that Simmons promises is of adaptive significance, to be sure, as it centrally tells that most primal of stories, one person's struggle against vicious and vastly powerful forces.

'Some places are too evil to be allowed to exist', the narrator tells us; 'Calcutta is such a place' (Simmons 1985: 1). Calcutta' is immediately established as the locale of the events that are to unfold, and provides an example of the importance of setting in horror fiction. In T. E. D. Klein's 1984 novel The Ceremonies, itself a fine study in the importance of physical setting to atmosphere, the protagonist Jeremy Freirs travels from Manhattan to rural New Jersey to write his thesis. He is casting about for an appropriate title: 'The Something Something Something of the Gothic Imagination; he would figure
1. The official spelling is now Kolkata, but to avoid confusion I will stick with the original spelling of the novel throughout this article. 
2. Incidentally, the only place where simmons' plot's wheels creak is where the cuteness of baby Victoria is overly emphasized The jaded horror reader will infer from plot-irrelevant scenes of intense fatherdaughter bonding (e.g. Simmons 1985 192) that something very bad is going to happen to Victoria. Poe was probably right that the death of a beautiful woman is the most poetical topic - but the death of a child is surely, to mammalian species with strong emotional parent-offspring bonds, the most tragic, and an easy tool for the author who wishes to manipulate his or her audience's emotions. it out eventually [...] The Interplay of Setting and Character. Or, even more promising, Setting as Character' (Klein 1984: 16). Later on, Freirs writes of 'Gothic fantasy as literature of setting, mystery as literature of plot, science fiction as literature of ideas' (Klein 1984: 166). This is hyperbole, of course, as setting is important to all stories. As Joseph Carroll notes, 'the relation between organism and environment is a matrix concept prior to all social, psychological, and semiotic principles' (2004: 152) and thus 'setting or physical place' is 'an elemental component of literary meaning' (2001: 296-97). But maybe setting is particularly important in horror fiction: partly as a means to create the appropriate emotional atmosphere (cf. the beginning of Poe's 'The Fall of the House of Usher'), partly because horror is usually concerned with threats that emanate from the environment, whether supernatural monsters, monstrous humans, or other configurations of adverse forces. As Carroll notes, writers of fiction 'are like ethologists reporting on the behaviour of animals in their natural habitats. They present us not simply with social and moral agents acting out plots but rather with human organisms intricately enmeshed in their environments' (2001: 311). In horror fiction, those are environments that teem with dangers and threats, and the best works of horror convey a very keen sense of place. Many horror stories are even named after places (from Walpole's castle to Lovecraft's Innsmouth; from Shirley Jackson's Hill House to King's Duma Key). And monsters or monstrous events are often tied to specific places, like the haunted house, the cemetery, the dark woods or the scene of a crime.

The first words of the first chapter intensify the ominous atmosphere and widen the informational void: "Don't go, Bobby," said my friend' (Simmons 1985: 2). We learn that the narrator, the literary man Robert Luczak, has accepted a brief to go to India to find the celebrated poet M. Das. Das has been supposed dead for eight years, but some evidence has emerged that he may be alive. Luczak leaves his well-known, quiet New Hampshire and his home - 'clean and open as a Scandinavian designer's dreams' (Simmons 1985: 13-14) - with his wife and their 5-month-old daughter and takes off for India. ${ }^{2}$ The small family is soon plunged into the dark, stinking chaos of Calcutta: an alien, dangerous and incomprehensible environment.

Even before the airplane lands, Luczak takes note of the chaotic aspect of Calcutta: 'Instead of the predictable urban progression of straight lines streets, highways, parking lots - Calcutta's myriad of fires seemed scattered and chaotic, a jumbled constellation broken only by the dark curve of the river'. The airport terminal is 'small and filthy', 'sweaty mobs' are 'jostling and shouting all around us', and there is a 'sense of hysteria in the pulses of white-shirted, saried humanity in the little building' (Simmons 1985: 18) - a hysteria that threatens to break out in violence at any time, as demonstrated by the porters violently competing for the newcomers' business (Simmons 1985: 20-21).

As the narrator reports:

Something about the Calcutta night worked directly upon the darkest regions of my mind. Brief clutches of an almost childlike fear tugged at my consciousness and were forced down again by the adult mind. The sounds of the night held no threat in and of themselves [...] but they had the same gut-wrenching, attention-getting effect that the sound of someone breathing under your bed at night would generate.

(Simmons 1985: 48-49)
1. 2. 3. 
Calcutta is represented as overcrowded, dangerous, decaying; it has the nightmarish quality of the imagined monster under the bed. In a sense, coming to Calcutta as envisioned in Song of Kali is like returning to a childlike state of irrational fear of the dark and the things that go bump in the night. ${ }^{3}$ It's a throwback to a more terrible time, whether in infancy or history. Calcutta is an insane place, much like Hill House; insane, hence unpredictable. Luczak struggles to make sense of the random, shifting patterns that he encounters, and along with him, the reader. According to Brian Boyd (2009), art is centrally about cognitive play with pattern; horror fiction often works its dark magic by presenting the reader (and protagonist) with a confusing and/or unsettling array of patterns, particularly in the shape of alien, cryptic environments and unpredictable, hostile foes. As what the narrator reports from his night-time bus ride through the city, en route to his hotel:

The buildings seemed ancient beyond age, decayed remnants of some forgotten millennium - some pre-human age - for the shadows, angles, apertures, and emptinesses did not fit the architecture of man [...] everywhere [there was] random movement caught in the corner of one's vision [...] and the sight of sheeted figures lying like corpses in the sidewalk shadows.

(Simmons 1985: 23)

These are all bewildering and alienating patterns to the narrator, patterns suggestive of an abstract, primeval danger. A few moments later, a boy throws the 'furry corpse' of a rat the size of a cat at the bus (Simmons 1985: 24). The next morning, the image of a human corpse greets Luczak from the pages of the local newspaper: 'a close-up photo of a corpse decomposing, face laid open like a burst rubber tire, glazed eyes protruding' (Simmons 1985: 27). All this, and more, in a few pages. Death and decay are so conspicuous as to constitute a veritable leitmotif, the leitmotif of the corpse. ${ }^{4}$ Luczak later finds himself in a 'decaying building in the belly of a dead city' (Simmons 1985: 32), and as the narratives progresses, rotting corpses become ever more prominent. In his search for M. Das, Luczak is introduced to the secret and feared cult of the Kapalikas, ruthless, Kaliworshipping thugs who sacrifice humans to their goddess and revive the dead in her honour. It transpires that M. Das actually did die (as a suicide), but was revived in an initiation process with the Kapalikas. As the young initiate, Jayaprakesh, reports to Luczak, he found the corpse required for the initiation ceremony in the town cremation grounds:

It was white - all white - the white of the bellies of dead carp washed up from the Hooghly. The skin had the texture of bleached, rotted rubber, like something peeled and shaped from the underside of a poisonous toadstool. The corpse was bloated taut; inflated from the awful internal pressure of expanding gases and organs swollen to the bursting point and beyond. Fractured splinters of ribs and bones were visible here and there in the puffy mass like sticks embedded in a rising dough [...] there came a whiff of foul river mud, and a sluglike thing appeared in one of the black eyeholes [...] I sensed the movement of many other things in the swollen mass.

(Simmons 1985: 88-89)
3. Simmons is neither the first nor the last to represent Calcutta as a very nasty place: "The "west" frequently pictures Calcutta as a scary urban setting, dominated by overpopulation, poverty and disease', as Erica Barbiani points out; 'Calcutta stands out as the archetype of the metropolitan nightmare' (2005, sect. 1.1). Song of Kali teems with Orientalist clichés and would probably lend itself willingly to a postcolonial reading, but that's not my concern here.

4. We can note in passing that Simmons' Summer of Night similarly features a generous helping of decomposing bodies. 
5. Kali means 'the black one', yet another darkness-related trope in horror mythology.
The readers of this journal are probably accustomed to a fair share of horror, but here Simmons really goes out of his way to invoke negative emotion in his readers. We later meet the revived poet Das, now in a state of advanced leprosy (Simmons 1985: 175-76); that description is no less revolting. As should be clear, Simmons powerfully - if crudely - plays on the reader's disgust response by dwelling on these horrible descriptions. Disgust is an adaptive response to pathogens in the environment (Curtis and Biran 2001), and a decomposing corpse is a highly contagious biological object. That a rotting corpse should inspire disgust is not surprising, in other words, and it is a recurrent, even predictable motif in horror fiction: the fear and disgust inspired by the dead and/or mutilated body is an emotion that the horror writer can easily elicit, because it is deeply coded into us to be aware of such evolutionarily recurrent dangers. The modern zombie story, for example, powerfully capitalizes on disgust responses to decomposing bodies (cf. Clasen 2010c).

If we take a closer look at another paradigmatic scene, the one where Luczak has been captured and drugged, we see another instance of the author attempting to manipulate the reader's evolved emotions. This scene evokes a primal fear scenario of predation in the dark: 'Blackness. Pain and blackness [...] I was lying on a cold stone floor. There was not the faintest gleam of light [...] It was a claustrophobic, inward-pressing darkness [...] What if they have blinded me?' (Simmons 1985: 199-200). Luczak is not blinded, but the darkness is total. Freud famously claimed in 'The Uncanny' that the fear of blindness is 'quite often a substitute for the fear of castration' (2003: 139), but it seems to me more plausible that it is a wholly rational fear of being unable to navigate in a potentially dangerous environment. [To be sure, Luczak fears for assailants lurking in the dark: 'The Kapalikas could be back at any second [...] I began to run' (Simmons 1985: 201).] Sight is the chief means by which humans navigate and orient themselves to their surroundings. Other species use other means, such as smell or hearing. A bat would be terrified to lose its hearing, a mole to lose its tactile sense.

As it happens, Luczak confronts not fierce thugs but a statue of Kali, the goddess of death and destruction, among other things. ${ }^{5}$ Incredibly, the statue appears to have come alive; by the glow of a burning book of matches, Luczak sees a thing that

crouched on six limbs like some huge and hairless spider, but fingers groped and twitched at the end of some of its limbs. The neck arched, jutting the gaunt face toward me [...] Kali opened her mouth and hissed at me. Her jaw gaped wide. The crimson tongue slid out, five inches, ten inches; it unrolled like crimson, melting wax, until it touched the floor where it curled at the tip like a questing serpent and slid quickly across the cold stone toward me. I screamed then.

(Simmons 1985: 202)

Interestingly, Luczak has no way of knowing the creature's intentions; for all he knows, it could be interested in some small-talk and a kiss. Yet his response is, all things considered, sensible. In his description, Simmons evokes spiders and snakes, two almost archetypal, evolutionarily relevant threats. Humans come into the world with a preparedness to acquire fear of certain objects, and snakes and spiders appear to be two such latent objects of phobia, as mentioned above. In the psychologist Martin Seligman's words, phobias 'comprise a relatively nonarbitrary and limited set of objects: agoraphobia, fear
1.

2.

3.

4.

5 .

6.

7.

8.

9.

10 .

11.

12.

13.

14.

15.

16.

17.

18.

19.

20.

21.

22.

23.

24.

25.

26.

27.

28.

29.

30.

31.

32.

33.

34.

35.

36.

37.

38.

39.

40.

41.

42.

43.

44.

45.

46.

47.

48.

49.

50.

51.

52. 
1. of specific animals, insect phobias, fear of heights, and fear of the dark, etc.' 2. As he adds, 'only rarely, if ever, do we have pajama phobias, grass phobias,

3. electric-outlet phobias, hammer phobias, even though these things are likely 4. to be associated with trauma in our world'. Rather, potentially phobic events 5. are 'related to the survival of the human species through the long course of evolution' (1971: 312). Simmons thus capitalizes on the likelihood of a correspondence between his protagonist's and his readers' intuitive response to the Kali-monster; a likelihood that is predicated on a common element in the structure of human affective makeup, that is, a propensity to find certain things nice and certain things nasty in a non-arbitrary distribution.

Luczak manages to escape the monster, but with the horrible knowledge that it is somewhere in the darkness with him. 'The scrabbling sounds were everywhere, cartilage scraping on stone and wood' (Simmons 1985: 203). The awareness that a predator is in the vicinity, coupled with uncertainty about its precise location and a supposition that it is aware of you, is apt to trigger a strong anxiety response. A similar reaction is observed in our primate cousins, for example bonnet macaques (cf. Coss et al. 2007), and it is an adaptive, predictable neurophysiological algorithm that is often capitalized upon by horror fictions. (The Blair Witch Project is a good example.)

As a horror novel, defined by its target affect, Song of Kali succeeds by effectively manipulating reader emotion. The only reason why Song of Kali can do this is that humans are similarly constructed; the reason why we are similarly constructed is that humans share a nature that is a product of evolution. Adapting to dangerous environments has been no small part of that process.

\section{THE SUPERNATURAL: METAPHORICALLY AND LITERALLY}

In the introduction to his 1979 collection Night Shift, Stephen King formulated a paradox: 'The thing under my bed waiting to grab my ankle isn't real. I know that, and I also know that if I'm careful to keep my foot under the covers, it will never be able to grab my ankle' (1979: 6). Similarly, Edith Wharton - the author of a number of highly unsettling ghost stories - famously said that while she didn't believe in ghosts, she was afraid of them. The fear or frisson engendered by the ghost story is, in Wharton's view, a matter of imagination rather than belief (Davies 2009). This notion is echoed by Peter Straub, who asserts that

I probably don't believe in anything supernatural [...] but my imagination really believes in it. And imagination is a powerful force that ought to be always reckoned with, ought to be always encouraged, since it creates a version of reality which should be taken seriously, if only for the insight it gives one into oneself. But it also reflects something at large, something at work in the actual world.

(Clasen 2009: 41)

Straub's metaphysical innuendo, the 'something at large', could be twisted to mean the forces of natural selection working on our species for millions of years, coming up with an organism that sees faces on Mars and is supersensitive to the 'chimney-corner whisper'. A number of scholars working on the cognitive science of religion are coming up with a model of human nature that accounts for the ubiquity of belief in invisible agents. On this view, '[s] upernatural agent concepts trigger our naturally selected agency-detection 
system, which is trip-wired to respond to fragmentary information, inciting perception of figures lurking in shadows and emotions of dread or awe' (Atran and Norenzayan 2004: 714).

Supernatural agents, then, are inherently interesting, partly insofar as they account for otherwise puzzling events (such as thunder in a pre-scientific understanding), partly because they break with intuitive understandings of ontology. The supernatural riffs on deep-seated, evolved structures in human nature; this is likely the reason for King's coy paradox, and for Lovecraft's observation on the atavistic power of fearsome objects. It's the reason why T. E. D. Klein, who describes himself as an atheist 'amazed that any thinking person could not be' (Kleffel 2008: 51), is attracted to themes of occult supernaturalism in his reading as well as his writing. And it explains why Simmons, who likewise says that 'I don't believe in anything supernatural' (Kleffel 2010, at 22:50), has been able to make a career out of telling stories of supernatural horror. In another interview, Simmons elaborates colourfully:

I don't believe in ghosts [...] I don't believe in vampires [...] I don't believe in demons, angels, astrology, werewolves, JFK conspiracy theories, Feng shui, utopias, God, Satan, pyramid power, Freud, Marx, Buddha, prayer, the power of positive thinking, poltergeists, reincarnation, UFO's, Bigfoot, grapho-analysis, whole grain cereals, Jesus, Patsy Ramsey's innocence, an afterlife or - fill in the blank. [...] I am, in John Keats's words, '... certain of nothing but the holiness of the Heart's affections and the truth of imagination.' If some of that truth of Imagination is to be found in novels labeled 'horror' or 'dark fantasy' or whatever they want to label them, then so be it. I'll do my best to write a good book.

(Gwinn and Wiater 2001: 186) 28.

The 'truth of the Imagination' that Simmons seems to be after is, in the case 30. of Song of Kali, to be found in his dark vision of Luczak's misfortunes and in 31. the emotional significance of the novel. The fantastical superstructure is in 32 . Simmons' hands a device, subordinate to his creative as well as his ideological 33. vision. Simmons does not wish to make a case for the existence of the super- 34 . natural, literally conceived; he uses in it a greater project, the project of telling 35. an absorbing story while conveying a certain world-view. The reason he can 36. do this is that the supernatural monsters of horror fiction are inherently, liter- 37. ally interesting, ontology-breaching, predatory and attention demanding as 38 . they are - and at the same time, they all but burst with metaphorical juiciness. 39. The eponymous monster of Simmons' novel is no exception.

It turns out that the poet M. Das has returned as a kind of vessel for Kali, the dark goddess. Kali is the focus and residue of all the atavistic urges and actions that ten thousand years of conscious strivings had hoped to put behind'. The long poem that Das writes consists of smaller elements, each of which

reflected a rip in the sense-deafening fabric of reality, a rip through which the Song of Kali could be faintly heard [...] In this century [i.e., the twentieth] the Song of Kali had become a chorus. The smoke of sacrifice rose to the clouded dwelling of Kali, and the goddess awoke to hear her song.

(Simmons 1985: 156)

1. 2. 3. 4. 5. 7. 8. 9. 
Thus, Kali is more than a monstrous deity; she becomes, to Simmons, a symbol for human vice and depravity, for the supposed barbarism of history, pre-modern and modern.

Joseph Carroll argues that literature 'and the other arts provide paradigmatic and emotionally saturated images of the world and of human experience, and it is through these images that people come to understand the emotional quality of the motives available to them' (2006: 42-43). Carroll argues that literature and its oral antecedents are adaptive in the biological sense, in that they help us to navigate the world more efficiently. Further, Carroll writes that literature

provides imaginative structures within which people can integrate the ancient, conserved elements of their nature - elements conserved from pre-mammalian systems of approach/avoidance, mammalian affectional systems, and systems of primate sociality - with the conceptual, thematic structures through which they make abstract, theoretical sense of the world.

(2006: 43)

This formulation accords well with the kind of work that Song of Kali performs. The novel allows the reader to become immersed in a virtual Calcutta replete with unsettling stimuli; to vicariously experience the narrator's struggle to make sense of an alien environment; to imaginatively confront monsters human and supernatural; but also to try on Simmons' ideological vision, which underwrites the fantastical structures of the novel. Song of Kali is a novel that fulfils the affective ambition of horror fiction generally, to be sure, but it aspires to more than dishing out fear and anxiety. Not that scaring cannot be a noble goal in itself: this is, after all, how horror fiction allows us to expand our experiential horizons, free of charge and risk, and to widen our emotional experience of the horrible.

But the novel also wants to impart a certain perspective on the world. Song of Kali conveys a powerful indictment of human depravity, and especially of the atrocities of recent history. Recently, on his website, Simmons described the twentieth century vividly as 'a swirling cesspool of endless blood and shit' (Simmons 2006). As a very tangible example of human evil, and as an example of how that theme figures prominently in the thematic structure of the novel, consider the death of Luczak's baby daughter: she is the random victim of a primitive crime, in that she is kidnapped, murdered and used as an inconspicuous holster in which to smuggle stolen gems across the border (Simmons 1985: 243-24).

Yet if all Simmons wanted with Song of Kali was to condemn human vice, he could have written a letter to the editor of the Colorado Daily. Instead, Simmons has constructed the emotional equivalent of a roller coaster with animated horrors and unexpected turns. The reader can join the ride for the sheer thrill-fun of it, but if the reader listens carefully, he or she will discern from the background noise a whispered litany that is Simmons' vision, his message. The volume of that vision is turned up towards the end of the ride, which terminates in a bleak vision of precarious existence in a dangerous, possibly deranged world. As John Clute puts it: 'Horror exercises its rage ripping open the one-way gates to truth; after which is silence, a deep transparency of utter rage' (2006: 88).

With Song of Kali, Simmons manages to hold the reader's attention with a disturbing tale of supernatural horror, which has at its core a bleak vision 
of existentialist terror, but also conveys a certain conservative sensibility and affirms the value of the familiar. Simmons is able to capture and hold the reader's attention because he gives narrative shape to emotionally saturated scenarios that seem relevant to a prey species. In Joseph Carroll's terminology, Simmons is like an ethologist, reporting on the behaviour of a fictional character in a fictional environment that is teeming with danger and threat.

Had not evolution fine-tuned us for a dangerous life, we would have no horror fiction today. Human evolutionary history is littered with the corpses of those who were not vigilant enough, not fearful enough, not paranoid enough. Thus, today, we sit on a pile of bones of those who never became ancestors. It is sweetly ironic that many of us sit there reading novels like Song of Kali.

\section{REFERENCES}

Atran, S. and Norenzayan, A. (2004), 'Religion's Evolutionary Landscape: Counterintuition, Commitment, Compassion, Communion', Behavioral and Brain Sciences, 27: 6, pp. 713-70.

Barbiani, E. (2005), 'Kalighat, the Home of Goddess Kali: the Place Where Calcutta is Imagined Twice: a Visual Investigation into the Dark Metropolis', Sociological Research Online, 10: 1, n.p.

Barret, H. C. (2005), 'Adaptations to Predators and Prey', in D. Buss (ed), The Handbook of Evolutionary Psychology, New York: John Wiley and Sons, pp. 200-23.

Barrett, J. L. (2004), Why Would Anyone Believe in God?, Walnut Creek, CA: Altamira Press.

Barkow, J. (2006), Missing the Revolution: Darwinism for Social Scientists, Oxford: Oxford University Press.

Botting, F. (1996), Gothic, London: Routledge.

Boyd, B. (2007), 'Tails Within Tales', in L. Simmons and P. Armstrong, (eds), Knowing Animals, Leiden: Brill, pp. 217-43.

(2009), On the Origin of Stories, Cambridge, MA: Harvard University Press.

Boyer, P. (2002), Religion Explained, London: Vintage.

Carroll, J. (2001), 'The Ecology of Victorian Fiction', Philosophy and Literature, 25: 2, pp. 295-313.

- (2004), Literary Darwinism, New York: Routledge.

(2006), 'The Human Revolution and the Adaptive Function of Literature', Philosophy and Literature, 30: 1, pp. 33-49.

(2010), 'Three Scenarios for Literary Darwinism', New Literary History, 41: 1, pp. 53-67.

Carroll, N. (1990), The Philosophy of Horror, New York: Routledge.

Clasen, M. (2009), 'A Conversation with Peter Straub', Cemetery Dance, 61: 1, pp. $40-48$.

- (2010a), 'The Horror! The Horror!', The Evolutionary Review, 1: 1, pp. 112-19.

(2010b), 'Vampire Apocalypse: A Biocultural Critique of Matheson's I Am Legend', Philosophy and Literature, 34: 2, pp. 313-28.

- (2010c), 'The Zombie Apocalypse: A Bio-Psychological Look at the Undead Other', Otherness: Essays and Criticism, 1: 1, pp. 1-23.

Clute, J. (2006), The Darkening Garden: A Short Lexicon of Horror, Seattle: Payseur \& Schmidt.

1. 2. 3. 4. 5. 6. 7. 8. 9. 10. 11. 12. 13. 
Cooke, B. (2002), Human Nature in Utopia: Zamyatin's We, Evanston: Northwestern University Press.

Coss, R. G. (2003), 'The Role of Evolved Perceptual Biases in Art and Design', in E. Voland and K. Grammar (eds), Evolutionary Aesthetics, Berlin: Springer, pp. 69-130.

Coss, R. G. and Goldthwaite, R. O. (1995), 'The Persistence of Old Designs for Perception', in N. S. Thompson (ed), Perspectives in Ethology, volume II: Behavioral Design, New York: Plenum Press, pp. 83-148.

Coss, R. G., McCowan, B. and Ramakrishnan, U. (2007), 'Threat-Related Acoustical Differences in Alarm Calls by Wild Bonnet Macaques (Macaca radiata) Elicited by Python and Leopard Models', Ethology, 113: 4, pp. 352-67.

Curtis, V. and Biran, A. (2001), 'Dirt, Disgust, and Disease: Is Hygiene in Our Genes?', Perspectives in Biology and Medicine, 44: 1, pp. 17-31.

Darwin, C. (1859), On the Origin of Species, Hertfordshire: Wordsworth.

— (1871), The Descent of Man, and Selection in Relation to Sex, London: Penguin.

- (1872), The Expression of the Emotions in Man and Animals, Oxford: Oxford University Press.

Davies, D. S. (2009), 'Introduction', in The Ghost Stories of Edith Wharton, in D. S. Davies (ed), Hertfordshire: Wordsworth, pp. vii-xii.

Davis, H. and McLeod, S. L. (2003), 'Why Humans Value Sensational News: An Evolutionary Perspective', Evolution and Human Behavior, 24: 3, pp. 208-16.

Ekman, P. (1992), 'Are There Basic Emotions?', Psychological Review, 99: 3, pp. 550-53.

Freud, S. (2003), The Uncanny (trans. D. McLintock), New York: Penguin, pp. 121-62.

Gottschall, J. (2008), The Rape of Troy, Cambridge: Cambridge University Press.

Gwinn, B. and Wiater, S. (2001), Dark Dreamers: Facing the Masters of Fear, Baltimore, MD: Cemetery Dance Publications.

Hart, D. and Sussman, R. W. (2009), Man the Hunted: Primates, Predators, and Human Evolution, 2nd ed., Boulder, CO: Westview Press.

Isbell, L. A. (2006), 'Snakes as Agents of Evolutionary Change in Primate Brains', Journal of Human Evolution, 51: 1, pp. 1-35.

King, S. (1979), Night Shift, London: Hodder and Stoughton.

Kleffel, R. (2008), 'A Conversation with T. E. D. Klein', Cemetery Dance, 58: 1, pp. 48-53. (2010), 'Interview with Dan Simmons', Rick Kleffel's The Agony Column, http://www.bookotron.com/agony/audio/2010/2010-interviews/dan_ simmons-2010.mp3. Accessed 6 September 2010.

Klein, T. E. D. (1984), The Ceremonies, London: Pan Books.

Lovecraft, H. P. (1973), Supernatural Horror in Literature, New York: Dover Publications Inc.

Marks, I. M. and Nesse, R. M. (1994), 'Fear and Fitness: An Evolutionary Analysis of Anxiety Disorders', Ethology and Sociobiology, 15: 5/6, pp. 247-61.

New, J., Cosmides, L. and Tooby, J. (2007), 'Category-specific attention for animals reflects ancestral priorities, not expertise', Proceedings of the National Academy of Science, 104: 42, pp. 16598-603. 
Mathias Clasen

Norden, E. ([1983] 1988), 'Playboy Interview: Stephen King', in T. Underwood 1. and C. Miller (eds), Bare Bones: Conversations on Terror with Stephen King, 2. New York: Warner Books, pp. 24-56. 3.

Öhman, A. (2000), 'Fear and Anxiety: Evolutionary, Cognitive, and Clinical 4. Perspectives', in M. Lewis and J. M. Haviland-Jones (eds), Handbook of 5. Emotions, 2nd ed., New York: Guilford Press, pp. 573-93. 6.

Öhman, A. and Mineka, S. (2001), 'Fears, Phobias, and Preparedness: Toward 7. an Evolved Module of Fear and Fear Learning', Psychological Review, 108: 3, 8. pp. 483-522. 9.

Pinker, S. (2002), The Blank Slate, London: Penguin. 10.

Quammen, D. (2004), Monster of God, New York: W. W. Norton. 11.

Rakison, D. H. and Derringer, J. L. (2008), 'Do Infants Possess an Evolved 12. Spider-Detection Mechanism?', Cognition, 107: 1, pp. 381-393. 13.

Seligman, M. E. P. (1971), 'Phobias and Preparedness', Behavior Therapy, 2: 3, 14. pp. 307-20. 15.

Simmons, D. (1985), Song of Kali, London: Gollancz/Orion. 16.

— (1991), Summer of Night, London: Headline. 17.

_ (2006), 'May-June 2006 Message from Dan', Dan Simmons - Author's 18. Official Website, http://www.dansimmons.com/news/message/2006_05. 19. htm. Accessed 6 September 2010.

Swanger, D. (2008), 'Shock and Awe: The Emotional Roots of Compound 21. Genres', The New York Review of Science Fiction, 20: 5, pp. 1, 8-18. 22.

Wilson, E. O. (1975), Sociobiology, Cambridge, MA: Harvard University Press. 23.

SUGGESTED CITATION 25.

Clasen, M. (2011), 'Primal fear: A Darwinian perspective on Dan Simmons' Song 26. of Kali', Horror Studies 2: 1, pp. 89-104, doi: 10.1386/host.2.1.89_1 27.

\section{CONTRIBUTOR DETAILS 29.}

Mathias Clasen is a doctoral candidate at Aarhus University, Denmark, work- 31. ing on a cognitive-evolutionary approach to supernatural horror fiction. He 32. has published on zombies, vampires, Peter Straub, Richard Matheson and 33. other creatures that go bump in the night. 34 .

Contact: Department of English, Aarhus University, Jens Chr. Skous Vej 5, 35. DK-8000 Aarhus C, Denmark. 36. E-mail: engmc@hum.au.dk 37. 